\title{
Omnivory by the coastal marine copepods Centropages hamatus and Labidocera aestiva
}

\author{
Walter J. Conley* and Jefferson T. Turner \\ Biology Department, Southeastern Massachusetts University, North Dartmouth, Massachusetts 02747, USA
}

\begin{abstract}
Omnivory by the 2 coastal marine copepods Centropages hamatus (Lilljeborg) and Labidocera aestiva Wheeler was examined in laboratory grazing and predation experiments. Cooccurring food items were utilized. C. hamatus ingested more carbon in the form of plant material $(\overline{\mathrm{x}}=$ $2.05 \mu \mathrm{gC}$ copepod $\left.\mathrm{d}^{-1} \mathrm{~d}^{-1}\right)$ than did $L$. aestiva $\left(\overline{\mathrm{x}}=0.66 \mu \mathrm{gC}\right.$ copepod $\left.{ }^{-1} \mathrm{~d}^{-1}\right)$. Conversely, L. aestiva ingested more carbon in the form of animal food $\left(\overline{\mathrm{x}}=3.35 \mu \mathrm{gC} \operatorname{copepod}^{-1} \mathrm{~d}^{-1}\right)$ than did C. hamatus $(\overline{\mathrm{x}}=$ $0.98 \mu \mathrm{gC}$ copepod $\mathrm{d}^{-1} \mathrm{~d}^{-1}$ ). Rates of ingestion of copepod nauplii and phytoplankton by both $C$. hamatus and $L$. aestiva increased significantly with increasing food concentrations and temperatures. Average grazing and predation rates of $C$. hamatus and $L$. aestiva upon natural phytoplankton assemblages and nauplii appeared to follow biomass peaks. The maximum field concentration of C. hamatus $\left(722 \mathrm{~m}^{-3}\right)$ appeared capable of daily ingesting means of $0.85 \%$ of phytoplankton carbon and $8.23 \%$ of the copepod nauplii present. Maximum field concentration of adult $L$. aestiva $\left(8 \mathrm{~m}^{-3}\right)$ appeared capable of ingesting means of only $0.01 \%$ of phytoplankton carbon and $0.29 \%$ of the copepod nauplii present.
\end{abstract}

\section{INTRODUCTION}

Knowledge of copepod feeding habits is necessary for understanding marine ecosystem trophodynamics Analyses of copepod gut contents, feeding appendages, and results of feeding experiments have revealed that various copepods eat both phytoplankton and animal food and hence are omnivores (Marshall, 1924, 1973; Wickstead, 1962; Anraku and Omori, 1963; Mullin, 1966; Haq, 1967; Robertson and Frost, 1977; Turner, 1978, 1984a, b, in press; Paffenhöfer and Knowles, 1980). However, the natural diets of most marine planktonic copepods are so ill defined that it is still impossible to assign them realistically to proper trophic levels. Further, there is little information on the relative roles of phytoplankton and animal food in the diets of omnivorous marine copepods.

The present study addresses the relative importance of carnivory and herbivory for 2 species of inshore copepods, Centropages hamatus (Lilljeborg) and Labidocera aestiva Wheeler. There is little information on the feeding habits of these species. C. hamatus has been shown to feed upon unialgal cultures (Klein Breteler, 1980; Kiørboe et al., 1982) and unnatural prey

- Present address: Department of Marine Science, University of South Florida, 140 Seventh Avenue South, St. Petersburg, Florida 33701, USA items (Artemia nauplii) in the laboratory (Anraku and Omori, 1963). Members of the genus Labidocera (and the entire family Pontellidae) have often been assumed to be primarily carnivorous (Anraku and Omori, 1963; Gauld, 1966; Itoh, 1970; Landry, 1978). However, there is evidence of herbivory by several pontellid species, including $L$. aestiva (Lebour, 1922; Turner, 1977, 1978, in press).

The relative importance of phytoplankton and animal food has been examined by several investigators but rarely on naturally co-occurring foods. Wickstead (1962) and Itoh (1970) separated various copepods into 3 categories on the basis of gut analysis: herbivores, mixed feeders, and carnivores. Robertson and Frost (1977) offered cultured diatoms or Artemia nauplii to the omnivorous copepod Aetideus divergens. Monospecific cultures of a diatom (Thalassiosira fluviatilis) and unnatural prey items (Artemia nauplii) were offered to 6 species of neritic copepods by Anraku and Omori (1963), and the results were discussed with regard to mouthpart morphology. All of these techniques (gut analyses, mouthpart morphology, and feeding experiments using unialgal cultures and Artemia nauplii as food) were utilized by Mullin (1966) to determine the feeding habits of various copepods from the Indian Ocean. The continental shelf copepods Centropages velificatus (reported as C. furcatus) and 
Temora stylifera also proved omnivorous when allowed to feed upon unialgal cultures and laboratory reared nauplii (Paffenhöfer and Knowles, 1980).

Various omnivory experiments have offered animal and plant food types in the same container (Landry, 1981), separately (Robertson and Frost, 1977; Paffenhöfer and Knowles, 1980), or together (Anraku and Omori, 1963; Mullin, 1966). While this may have affected the results of some of the above experiments (Landry, 1981), Lonsdale et al. (1979) found no significant decrease in predation by the omnivorous copepod Acartia tonsa in the presence of an alternative food source.

A problem with laboratory feeding studies utilizing cultured foods is their inherent artificiality. However, several recent measurements of copepod ingestion rates on natural assemblages of food have employed phytoplankton quantification by either electronic particle counters (Poulet, 1973, 1974, 1978; Richman et al., 1977; Cowles, 1979; Dagg et al., 1980, 1982; Harris, 1982), copepod gut fluorescence (Boyd et al., 1980; Dagg and Grill, 1980; Dagg and Wyman, 1983), or microscopic examination (Huntley, 1981; Turner and Anderson, 1983). The latter approach was adopted in the present study, and ingestion rates of Centropages hamatus and Labidocera aestiva were determined by microscopic enumeration utilizing natural phytoplankton assemblages and co-occurring copepod nauplii as food. In addition, quantitative samples of the field populations of C. hamatus, L. aestiva, and food organisms (phytoplankton and nauplii), were collected in order to estimate the potential impact of feeding by the target copepods on a natural estuarine plankton assemblage.

\section{MATERIALS AND METHODS}

Experiments were performed on an approximately weekly to biweekly schedule from 11 April to 30 September, 1980. All collections were made in the Westport River estuary, Massachusetts $\left(41^{\circ} 34^{\prime} \mathrm{N} 71^{\circ} 05^{\prime} \mathrm{W}\right)$. Experimental animals were collected at the surface and transported to the laboratory within 1 to $2 \mathrm{~h}$ at ambient field temperature. Estuarine water, containing natural phytoplankton, was collected at the same time and location as the experimental animals. In order to remove extraneous zooplankton, this water was screened through a $73 \mu \mathrm{m}$ mesh. All experiments were performed in $400 \mathrm{ml}$ subsamples in $473 \mathrm{ml}$ containers at field temperatures $\left(8\right.$ to $\left.23^{\circ} \mathrm{C}\right)$.

Adult Centropages hamatus or Labidocera aestiva were sorted from the zooplankton collections within 1 to $5 \mathrm{~h}$ of capture. Although it was impossible to similarly identify and stage live nauplii as they were being sorted, on each experimental date the same size and genus of nauplii were used in all containers. Subsequent to the experiments, wet mounts were made of the remaining nauplii and examined under a compound microscope. The nauplii were measured to the nearest $\mu \mathrm{m}$ and identified according to the criteria presented by Faber (1966).

On each experimental date, the experimental regime included: 2 control containers containing phytoplankton only, 4 grazing containers in which 5 to 10 adult male or female Centropages hamatus or Labidocera aestiva were allowed to graze in estuarine water containing phytoplankton, and 6 predation containers containing a single adult male or female C. hamatus or $L$. aestiva and either $25,37.5$, or 50 nauplii $1^{-1}$ in 0.45 $\mu \mathrm{m}$ filtered seawater.

Feeding experiments were performed in the dark, in a temperature controlled room set at field temperature, for 12 to $24 \mathrm{~h}$. Feeding containers were placed on a rotating plankton wheel ( 1 to $2 \mathrm{rpm}$ ) to retard algal sedimentation. Visual examination at the end of each experiment ensured that the copepods were still active. Experiments were terminated by preservation with formalin for the predation containers, or Utermöhl's solution (Guillard, 1973) for the grazed containers.

Phytoplankton concentrations were determined by microscopic enumeration in a Sedgwick-Rafter counting chamber following concentration by a factor of ten by sedimentation. Aliquots of at least 500 cells were counted to obtain statistical reliability (Guillard, 1973). Phytoplankton cells were measured with an ocular micrometer, cell volumes were determined, and phytoplankton carbon was estimated by the volume to carbon conversions of Mullin et al. (1966). Carbon ingestion of phytoplankton by Centropages hamatus and Labidocera aestiva was determined by the formula:

$$
I=24 \cdot\left(C_{\bar{x}}-C_{g}\right) / n \cdot t
$$

where $\mathrm{I}=$ ingestion rate $\left(\mu \mathrm{gC}\right.$ copepod $\left.^{-1} \mathrm{~d}^{-1}\right) ; \mathrm{C}_{\overline{\mathrm{x}}}=$ mean carbon concentration $\left(\mu \mathrm{gC} \mathrm{l}^{-1}\right)$ of the controls; $\mathrm{C}_{g}$ $=$ carbon concentration $\left(\mu \mathrm{gC}^{-1}\right)$ of the grazed containers; $\mathrm{t}=$ duration of the experiment in $\mathrm{h} ; \mathrm{n}=$ number of grazers. This equation is essentially the same as that utilized by Paffenhöfer (1971) expessed as carbon rather than particle volume. If the carbon concentration in the grazed container was not lower than that in the controls by an amount greater than that of the counting error, then it was assumed that no grazing had occurred. Percent error, on each sampling date, was calculated as:

$$
\% \mathrm{E}=\left(\left[\mathrm{C}_{2}-\mathrm{C}_{1}\right] / \mathrm{C}_{\overline{\mathrm{x}}}\right) \cdot 100
$$

where $\mathrm{C}_{1}=$ carbon concentration $\left(\mu \mathrm{gC}^{-1}\right)$ in the first control; $\mathrm{C}_{2}=$ carbon concentration $\left(\mu \mathrm{gC} \mathrm{l}^{-1}\right)$ in the 
second control; $\mathrm{C}_{\overline{\mathrm{x}}}=$ mean carbon concentration $(\mu \mathrm{gC}$ $\left.\mathrm{l}^{-1}\right)$ in the control containers.

Predation upon nauplii by adult copepods was determined on each experimental date by subtracting the number of nauplii remaining at the end of each experiment from the number initially introduced. Nauplii were recovered on a $20 \mu \mathrm{m}$ mesh screen, since repeated trials revealed that such recovery was complete. With few exceptions, the nauplii employed in the experiments were those of Acartia tonsa or A. hudsonica; hence naupliar carbon was estimated using Landry's (1978) carbon values for the appropriate sizes of Acartia spp. nauplii. However, on 24 and 28 June, 1980, Acartia spp. nauplii were essentially absent. Thus, nauplii of Pseudocalanus minutus s. 1. were utilized on these dates. Carbon values for these nauplii were estimated from length: carbon relationships (Landry, 1978) for the morphologically similar (Faber, 1966) Paracalanus sp. nauplii.

In order to present ingestion of both phytoplankton and nauplii on a ration basis (\% of copepod body carbon ingested per individual per unit time) carbon values for male and female Centropages hamatus and Labidocera aestiva were determined with a HewlettPackard 185B CHN analyzer.

In order to quantify field populations of Centropages hamatus, Labidocera aestiva, and nauplii, surface tows were made with $73 \mu \mathrm{m}$ mesh nets (for nauplii) and 363 $\mu \mathrm{m}$ mesh nets (for adult copepods) equipped with flowmeters. Due to the relatively shallow depth (ca $4 \mathrm{~m}$ ), and rapid current velocity (maximum $2.5 \mathrm{kts}$; US Department of Commerce, 1972), it is not likely that horizontal stratification occurred at the sampling station. Samples were collected on all experimental dates, preserved in 5 to $10 \%$ formalin: seawater solutions, and split with a Folsom plankton splitter. Aliquots of 500 to 1000 individuals were counted and identified for each tow. Phytoplankton field populations (for the $<73 \mu \mathrm{m}$ fraction) were determined from control samples.

\section{RESULTS}

The phytoplankton was dominated, throughout the study, by small (nominally 5 to $10 \mu \mathrm{m}$ ) nanoflagellates and chlorophytes. These cells comprised most of the carbon content of the phytoplankton. Carbon values fluctuated between 52.95 and $206.57 \mu \mathrm{gC} \mathrm{l}^{-1}$ (Fig. 1a). In September, a bloom of Peridinium trochoideum (maximum $=68$ cells $\mathrm{ml}^{-1}$ ) equaled or exceeded the carbon contribution of the nanoplankton. In August, Skeletonema costatum (maximum $=1,603 \mathrm{cells} \mathrm{ml}^{-1}$ ) was present in the same order of magnitude as, but never exceeding, the carbon contribution of the nanoplankton. Gymnodinium nelsoni $($ maximum $=31 \mathrm{cells}$ $\mathrm{ml}^{-1}$ ) and Leptocylindricus danicus (maximum = 54 cells $\mathrm{ml}^{-1}$ ) also contributed significantly in late August.

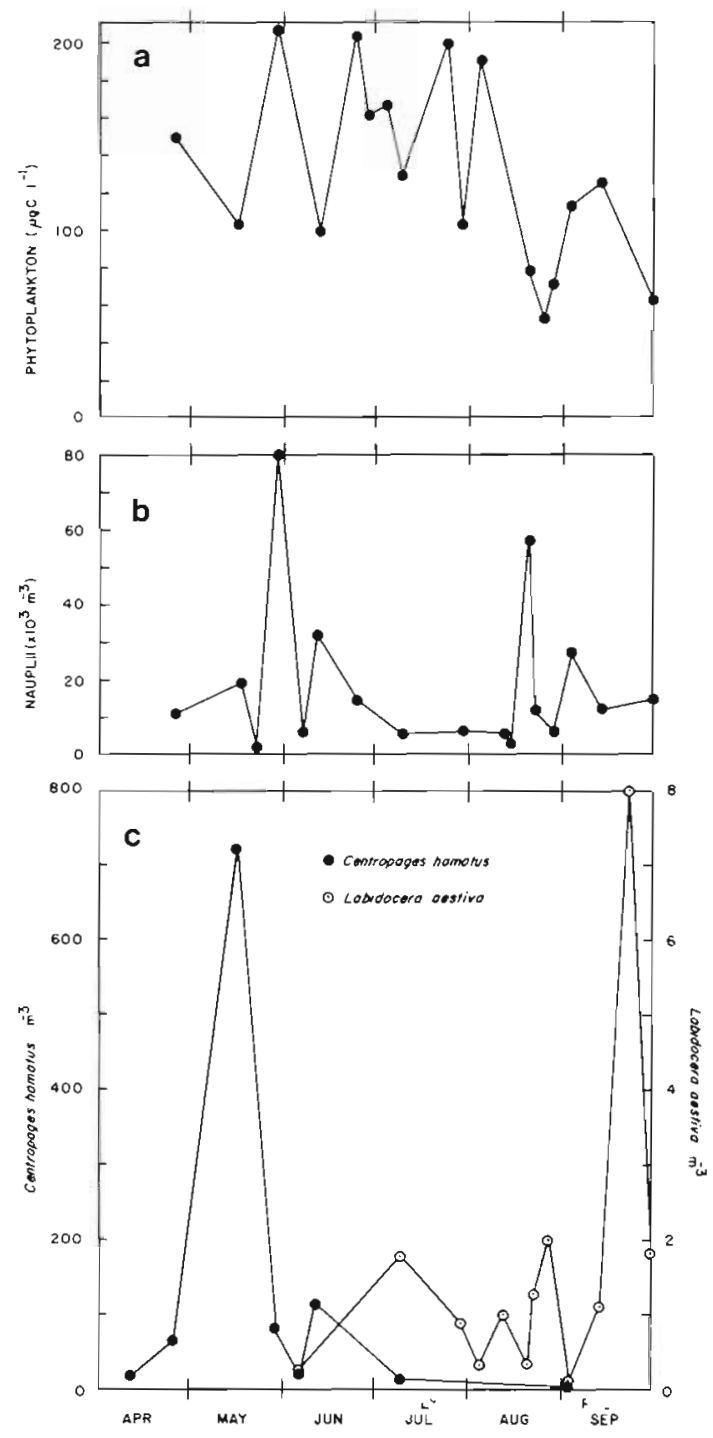

Fig. 1. Centropages hamatus and Labidocera aestiva. Field concentrations of phytoplankton (a), copepod nauplii (b), and adults (c) (males and females combined). Scales differ by 2 orders of magnitude for adult abundance

The zooplankton was dominated, in terms of numbers, by copepod nauplii. These comprised 87.0 to $99.0 \%$ of the total number of animals collected on each sampling date (Conley, 1983). The maximum number of nauplii $\left(80,304 \mathrm{~m}^{-3}\right)$ was collected on 29 May, 1980 (Fig. 1b). The nauplii, throughout the study, consisted mostly of Acartia spp. nauplii. Centropages hamatus was present at the initiation of the study and reached its period of maximum abundance $\left(722 \mathrm{~m}^{-3}\right)$ in midMay (Fig. 1c). This species was represented by small numbers throughout the summer months and was 
absent from the study area by mid-September. Labidocera aestiva was first observed in early June and was never abundant in the net collections. Maximum abundance $\left(8 \mathrm{~m}^{-3}\right)$ occurred in late September (Fig. 1c).

Grazing rates for Centropages hamatus (Fig. 2) ranged from undetectable to $7.29 \mu \mathrm{gC}$ copepod ${ }^{-1} \mathrm{~d}^{-1}$, with an overall average of $2.05 \mu \mathrm{gC}$ copepod $^{-1} \mathrm{~d}^{-1}$ (Table 1). Utilizing the carbon values for adult $C$. hamatus (Table 2), grazing represented means of 14.49
Since grazing rates for Centropages hamatus were determined over a wide range of temperatures (10 to $22{ }^{\circ} \mathrm{C}$ ) and a relatively narrow range of phytoplankton concentrations $\left(98.80\right.$ to $206.57 \mu \mathrm{gC}^{-1}$ ), the ingestion rates were not significantly related to food concentration when considered separately. However, when the effects of the 2 independent variables are combined (stepwise multiple regression), the ingestion rate increases significantly (Table 3) with increasing temperature and concentration. Labidocera aestiva did not

Table 1. Centropages hamatus and Labidocera aestiva. Ingestion of natural food items. All ingestion rates expressed as $\mu \mathrm{gC}$ copepod $^{-1} \mathrm{~d}^{-1}$

\begin{tabular}{|llcccc|}
\hline Species & $\begin{array}{c}\text { Food type } \\
\text { offered }\end{array}$ & $\begin{array}{c}\text { Average } \\
\text { ingestion }\end{array}$ & $\begin{array}{c}\text { Minimum } \\
\text { ingestion }\end{array}$ & $\begin{array}{c}\text { Maximum } \\
\text { ingestion }\end{array}$ & $\begin{array}{c}\text { Standard } \\
\text { error }\end{array}$ \\
\hline C. hamatus & Phytoplankton & 2.05 & 0 & 7.29 & 0.41 \\
C. hamatus & Nauplii & 0.98 & 0 & 4.22 & 0.15 \\
L. aestiva & Phytoplankton & 0.66 & 0 & 2.62 & 0.23 \\
L. aestiva & Nauplii & 3.35 & 0 & 8.38 & 0.28 \\
\hline
\end{tabular}

Table 2. Centropages hamatus and Lapidocera aestiva. Carbon content of adults

\begin{tabular}{|lcrcr|}
\hline Species & $\begin{array}{c}\mu \mathrm{\mu gC} \\
\text { copepod }^{-1} \\
\text { (female) }\end{array}$ & $\mathbf{n}$ & $\begin{array}{c}\mu \mathrm{gC} \\
\text { copepod }\end{array}$ & $\mathbf{n}$ \\
(male) $^{-1}$ & \\
\hline C. hamatus & 14.22 & 80 & 12.71 & 70 \\
L. aestiva & 24.19 & 100 & 23.12 & 50 \\
\hline
\end{tabular}

and $16.05 \%$ of body carbon ingested per day by the females and males, respectively. Grazing rates for Labidocera aestiva were lower than those of $C$. hamatus. Grazing rates for $L$. aestiva (Fig. 2) ranged from undetectable to $2.62 \mu \mathrm{gC}$ copepod $\mathrm{d}^{-1} \mathrm{~d}^{-1}$, with an overall average of $0.66 \mu \mathrm{gC}$ copepod $\mathrm{d}^{-1} \mathrm{~d}^{-1}$ (Table 1 ). Utilizing the carbon values for adult $L$. aestiva (Table 2), grazing represented means of 2.73 and $2.85 \%$ of body carbon ingested per day by the females and males, respectively.

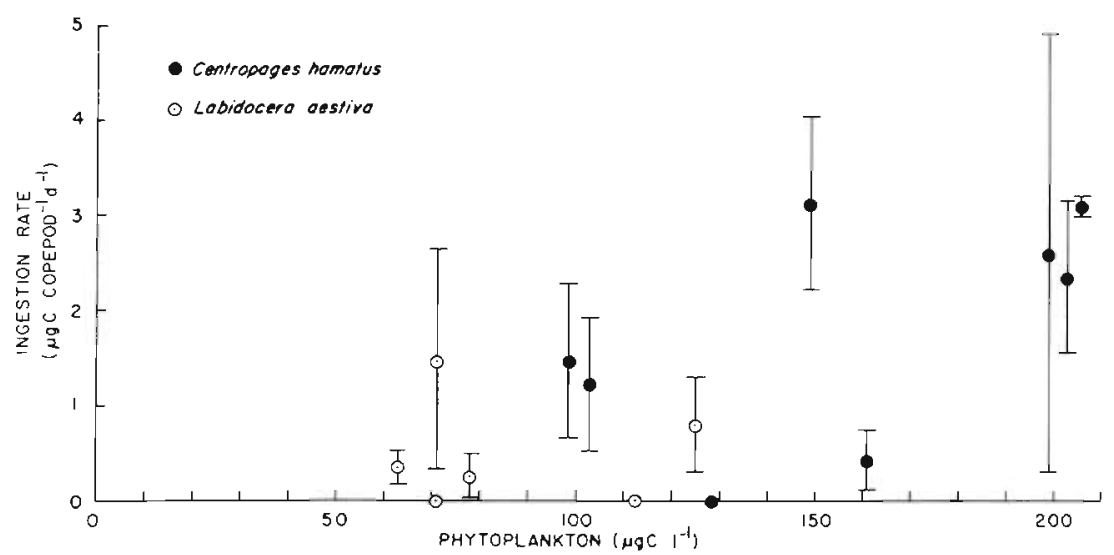

exhibit a significant increase in grazing rate with increased phytoplankton concentration. However, a combination of low field concentrations of both phytoplankton (Fig. 1a) and L. aestiva (Fig. 1c) and a relatively narrow temperature range $\left(21\right.$ to $25^{\circ} \mathrm{C}$ ) limited the scope of the investigation of the effects of temperature and food concentrations on its grazing.

Predation rates, over the natural range of naupliar concentrations offered, increased with increasing prey concentrations for both target species. Centropages hamatus (Fig. 3) ingested averages of 2.86, 4.03 and 5.29 nauplii $\mathrm{d}^{-1}$ at concentrations of 25.0, 37.5 and 50.0 nauplii $1^{-1}$, respectively. Labidocera aestiva (Fig. 3) ingested considerably more with averages of 9.15 , 13.89 and 22.35 nauplii $\mathrm{d}^{-1}$ at the same naupliar concentrations. In order to compare rates of ingestion of phytoplankton and nauplii on an equivalent basis, numbers of nauplii ingested vs. numbers offered were converted to carbon (Fig. 4). Ingestion rates ranged
Fig. 2. Centropages hamatus and Labidocera aestiva. Grazing (ingestion) rates of adults (males and females combined $\mu \mathrm{gC}$ copepod $^{-1}$ $\left.\mathrm{d}^{-1}\right)$ feeding on natural concentrations of phytoplankton. Means of 3 to 4 replicates; error bars: \pm standard error 
Table 3. Centropages hamatus and Lapidocera aestiva. Effect of the independent variables, food concentration and temperature,

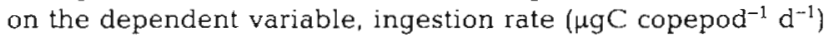

\begin{tabular}{|llll|}
\hline Species & Food type & Independent variable (s) & Significance level \\
\hline C. hamatus & Phytoplankton & Concentration & $\mathrm{P}<0.1021$ \\
C. hamatus & Phytoplankton & Concentration \& temperature & $\mathrm{P}<0.0253$ \\
C. hamatus & Nauplii & Concentration & $\mathrm{P}<0.0033$ \\
C. hamatus & Nauplii & Concentration \& temperature & $\mathrm{P}<0.0070$ \\
L. aestiva & Phytoplankton & Concentration & $\mathrm{P}<0.3013$ \\
L. aestiva & Phytoplankton & Concentration \& temperature & $\mathrm{P}<0.5656$ \\
L. aestiva & Nauplii & Concentration & $\mathrm{P}<0.0001$ \\
L. aestiva & Nauplii & Concentration \& temperature & $\mathrm{P}<0.0001$ \\
\hline
\end{tabular}

from 0.00 to $4.82 \mu \mathrm{gC}$ copepod ${ }^{-1} \mathrm{~d}^{-1}$ for C. hamatus and from 0.00 to $8.38 \mu \mathrm{gC}$ copepod ${ }^{-1} \mathrm{~d}^{-1}$ for L. aestiva. Regression analyses revealed that the slopes are significantly different from zero $(P<0.05)$ for both species. Further, L. aestiva ingested more animal prey than did $C$. hamatus at the same concentration of prey offered. In addition, the lower coefficient of regression for $C$. hamatus $(\mathrm{r}=0.51$ ) compared to $L$. aestiva $(\mathrm{r}=$ $0.77)$ may be indicative of the less predaceous nature of C. hamatus.

Predation and grazing rates, at food concentrations closest to those in the field, were converted to percent body carbon ingested and compared to field concentra-

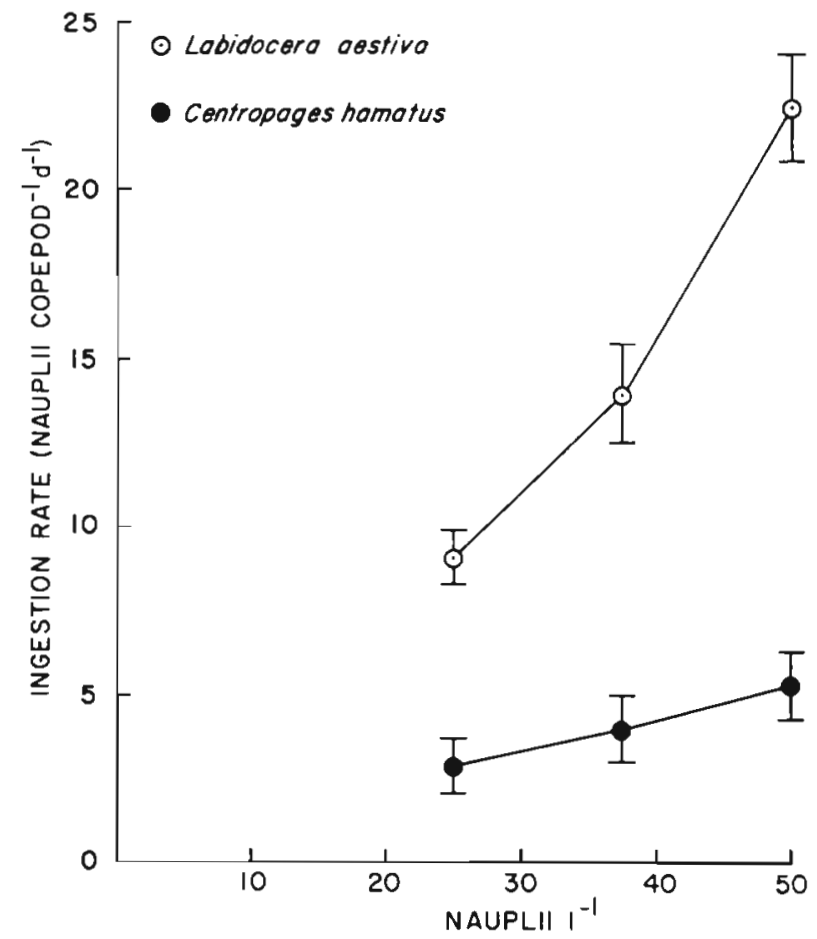

Fig. 3. Centropages hamatus and Labidocera aestiva. Predation (ingestion) rates of adults (males and females combined) feeding upon copepod nauplii (number of nauplii ingested copepod ${ }^{-1} \mathrm{~d}^{-1}$ ) over a range of natural concentrations. Means of 14 to 19 replicates; error bars: \pm standard error

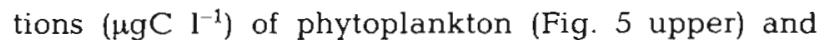
nauplii (Fig. 5 lower). Grazing rates for Centropages hamatus and Labidocera aestiva appear to track the peaks of phytoplankton abundance. When the combined effects of concentration and temperature are considered (stepwise multiple regression), the relationship is significant (Table 4). The mean grazing rates (Fig. 5 upper) follow the same patterns as those of the phytoplankton. Ingestion of nauplii by $C$. hamatus and $L$. aestiva were also significantly related to field concentrations of nauplii and temperature (Table 4).

The potential grazing and predation impact on natural phytoplankton assemblages in the Westport River estuary was extrapolated for each target copepod species during its period of maximum abundance (Table 5). The population of Centropages hamatus (maximum $=722 \mathrm{~m}^{-3}$ on 16 May, 1980) was capable of

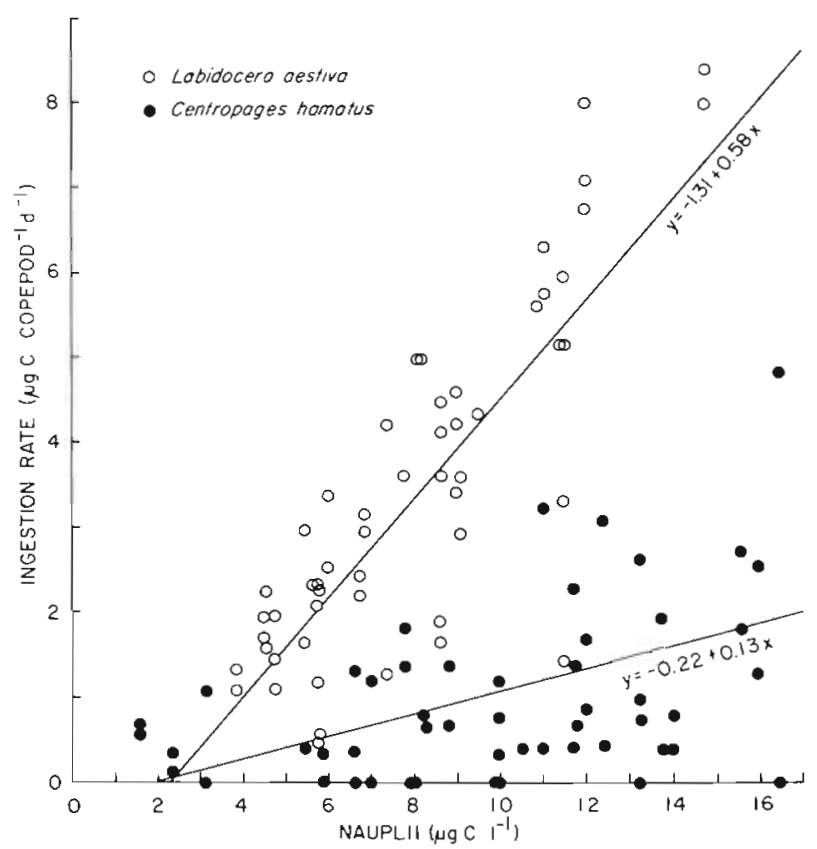

Fig. 4. Centropages hamatus and Labidocera aestiva. Predation (ingestion) rates of adults (males and females combined; $\mu \mathrm{gC}$ copepod $\mathrm{d}^{-1} \mathrm{~d}^{-1}$ ) feeding on copepod nauplii over a range of natural concentrations. Single determinations 


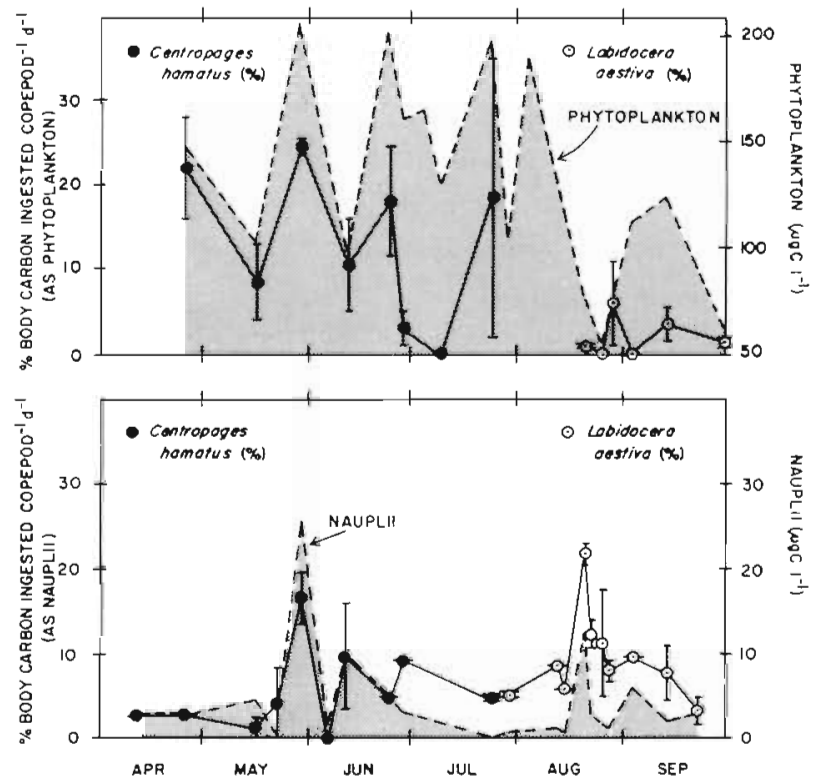

Fig. 5. Centropages hamatus and Labidocera aestiva. Percentage of body carbon ingested as phytoplankton vs. phytoplankton abundance (upper) and percentage of body carbon ingested as nauplii vs. field abundance of nauplii (lower) by adults (males and females combined). Means of 2 to 4 replicates; error bars: I standard error

Table 4. Centropages hamatus and Lapidocera aestiva. Effect of field concentrations of food items and temperature on ingestion rate ( $\%$ body carbon ingested copepod ${ }^{-1} \mathrm{~d}^{-1}$ ) for both species

\begin{tabular}{|lll|}
\hline Food type & $\begin{array}{c}\text { Independent } \\
\text { variable (s) }\end{array}$ & $\begin{array}{c}\text { Significance } \\
\text { level }\end{array}$ \\
\hline $\begin{array}{l}\text { Phytoplankton } \\
\text { Phytoplankton }\end{array}$ & $\begin{array}{l}\text { Concentration } \\
\text { Concentration }\end{array}$ & $\mathrm{P}<0.0005$ \\
& \& temperature & \\
Nauplii & Concentration & $\mathrm{P}<0.0005$ \\
Nauplii & Concentration & $\mathrm{P}<0.0001$ \\
& \& temperature & \\
\hline
\end{tabular}

Table 5. Centropages hamatus and Labidocera aestiva. Potential grazing and predation impact upon phytoplankton and nauplii in Westport River estuary

\begin{tabular}{|lccc|}
\hline Species & $\begin{array}{c}\text { Maxi- } \\
\text { mum } \\
\# \mathrm{~m}^{-3}\end{array}$ & $\begin{array}{c}\% \\
\text { Phytoplank- } \\
\text { ton carbon } \\
\text { removed }\end{array}$ & $\begin{array}{c}\text { Nauplii } \\
\text { removed }\end{array}$ \\
\hline C. hamatus & 700 & 0.85 & 8.23 \\
L. aestiva & 8 & 0.01 & 0.29 \\
\hline
\end{tabular}

daily grazing an average of $0.85 \%$ of the available phytoplankton carbon present on the same date. At the naupliar concentrations of 16 May, $1980\left(19.4 \mathrm{l}^{-1}\right), C$. hamatus was capable of ingesting an average of
$8.23 \%$ of the naupliar population. Maximum numbers of Labidocera aestiva in the field $\left(8 \mathrm{~m}^{-3}\right)$ were recorded on 22 September, 1980. Since no grazing data are available for that date, grazing rates from $13 \mathrm{Sep}-$ tember, 1980 were utilized. The population of L. aestiva was capable of daily ingesting an average of only $0.01 \%$ of the phytoplankton carbon available. The same field population of $L$. aestiva could daily ingest $0.29 \%$ of the available nauplii.

Therefore, even though individual Labidocera aestiva exhibit higher predation rates than those of individual Centropages hamatus, due to low numbers of $L$. aestiva, the predation impact of their population is lower than that of the more abundant $C$. hamatus. The highest feeding impact on the planktonic communities in the Westport River estuary is likely by the adults and juveniles of Acartia hudsonica and/or A. tonsa, which were the numerically dominant zooplankters in the estuary (Conley, 1983).

\section{DISCUSSION}

Both Centropages hamatus and Labidocera aestiva are omnivorous, but ingestion of one food type over another appears to be a matter of degree. Although $L$. aestiva was considered to be a carnivore by Anraku and Omori (1963), this species does ingest phytoplankton. Individual $L$. aestiva were often collected with green guts, indicating that herbivory may be more intense in the field than in our experiments. There is little doubt, however, that animal prey is preferred by this species. At natural food concentrations, rates of carbon ingestion of animal prey $(\overline{\mathrm{x}}=3.35 \mu \mathrm{gC}$ copepod $^{-1} \mathrm{~d}^{-1}$ ) were approximately $507 \%$ higher than those on phytoplankton $\left(\overline{\mathrm{x}}=0.66 \mu \mathrm{gC}\right.$ copepod $\left.{ }^{-1} \mathrm{~d}^{-1}\right)$. Conversely, $C$. hamatus ingested more plant than animal material. C. hamatus consumed an average of $209 \%$ more carbon when feeding upon natural concentrations of phytoplankton $\left(\bar{x}=2.05 \mu \mathrm{gC}\right.$ copepod $\left.^{-1} \mathrm{~d}^{-1}\right)$ than when feeding carnivorously $(\overline{\mathrm{x}}=0.98 \mu \mathrm{gC}$ copepod $^{-1} \mathrm{~d}^{-1}$ ). This indicates that $C$. hamatus is less predaceous, when feeding on natural prey items, than when feeding on artificial prey items such as Artemia nauplii (Anraku and Omori, 1963). Artemia nauplii are considerably larger, more sluggish, and therefore easier to capture, than Acartia spp. nauplii. Animal prey also appears unnecessary for growth and reproduction of $C$. hamatus, since this species has been successfully reared in the laboratory on phytoplankton cultures (Klein Breteler, 1980).

In a similar study of copepod omnivory by Paffenhöfer and Knowles (1980), Centropages velificatus ingested more animal prey than Temora stylifera, although both were omnivorous. Paffenhöfer and 
Knowles' results were discussed in relation to the swimming behavior of the predators and their prey. $T$. stylifera was described as a 'cruising' copepod, swimming almost constantly while creating a strong feeding current. This type of behavior could lead to maximum particle encounter. However, the strong feeding current could also be more readily detected by the naupliar prey, thereby allowing a greater chance of escape. $C$. velificatus was described as a 'hop and sink' swimmer, creating a relatively weak feeding current. This type of behavior would allow for 'ambush' predation since the copepod could more readily achieve proximity to the prey nauplii and once a nauplius is close to such a predator (within a few $\mathrm{mm}$ ) and at a certain angle towards its feeding appendages, there is little chance of escape' (Paffenhöfer and Knowles, 1980)

Since Labidocera exhibits a 'cruising' type behavior and Centopages hamatus is a 'hop and sink' swimmer, the results of the present study might seem contradictory to those of Paffenhöfer and Knowles (1980). However, $L$. aestiva creates a feeding current noticeably weaker than does $C$. hamatus. The weaker current, in combination with a 'cruising' type swimming behavior, could allow for a greater area of search while concurrently preventing detection by prey items. In addition, our results combined with those of Paffenhöfer and Knowles form an omnivory continuum, in that Temora appears more herbivorous and less carnivorous than Centropages, whereas Centropages appears more herbivorous and less carnivorous than Labidocera.

The advantage of omnivory in estuarine systems characterized by pulses of phytoplankton (Martin, 1965, 1970; Bruno et al., 1983; Turner et al., 1983) and microzooplankton (Turner, 1982; Conley, 1983) is obvious. The ability of some estuarine copepods to adjust their ingestion rates according to the relative abundance of food items has been demonstrated here (Fig. 5) and for various estuarine copepods by Poulet (1973, 1974, 1978). Further, Acartia tonsa, the most abundant summer copepod in temperate west Atlantic estuaries (Hulsizer, 1976; Turner, 1982), is also capable of supplementing its diet with animal prey in the form of copepod nauplii (Lonsdale et al., 1979).

It appears that adjustive omnivory is not restricted to estuarine copepods. The oceanic copepod Calanus pacificus ingested more animal prey as phytoplankton concentrations dropped and more plant material when phytoplankton was abundant (Landry, 1981). Turner (1984a) also noted an increase in the occurrence of crustacean appendages in the fecal pellets of the shelf copepod Eucalanus pileatus at stations where phytoplankton numbers were low.

Although it has long been known that most plank- tonic copepods are omnivores (Lebour, 1922; Marshall, 1924), previous quantitative comparisons of herbivorous and carnivorous feeding of copepods upon natural food items have been rare (Paffenhöfer and Knowles, 1980; Landry, 1981). In the absence of additional studies for numerous abundant copepod taxa, it will be impossible to assign these consumers to their proper niches in marine food webs. This will preclude realistic understanding or quantification of marine trophodynamics.

Acknowledgements. We thank Leah Curran for technical support, Teresa Hastings for aid in field collections and manuscript preparation, and the Biology Department, Southeastern Massachusetts University, for partial funding of this research

\section{LITERATURE CITED}

Anraku, M., Omori M. (1963). Preliminary survey of the relationship between the feeding habits and the structure of the mouthparts of marine copepods. Limnol. Oceanogr. 19: $446-451$

Boyd, C. M., Smith, S. L., Cowles, T. J. (1980). Grazing patterns of copepods in the upwelling system off Peru. Limnol. Oceanogr. 25: 583-596

Bruno, S. F., Staker, R. D., Sharma, G. M., Turner, J. T. (1983). Primary productivity and phytoplankton size fraction in a temperate north Atlantic estuary. Estuaries 6: 200-211

Conley, W. J. (1983). A comparison of herbivory and carnivory for two coastal marine copepods. M. S. thesis, Southeastern Mass. University

Cowles, T.J. (1979). The feeding response of copepods from the Peru upwelling system: food size selection. J. mar. Res. 37; 601-622

Dagg, M. J., Grill, D. W. (1980). Natural feeding rates of Centropages typicus females in the New York Bight. Limnol. Oceanogr. 25: 597-609

Dagg, M. J., Wyman, K. D. (1983). Natural ingestion rates of the copepods Neocalanus plumchrus and $N$. cristatus calculated from gut contents. Mar. Ecol. Prog. Ser. 13: 37-46

Dagg, M. J., Cowles, T., Whitledge, T., Smith, S., Howe, S. Judkins, D. (1980). Grazing and excretion by zooplankton in the Peru upwelling system during April 1977. Deep Sea Res. 27: 43-59

Dagg, M. J., Vidal, J., Whitledge, T. E., Iverson, R. L., Goering, J. J. (1982). The feeding, respiration, and excretion of zooplankton in the Bering Sea during a spring bloom. Deep Sea Res. 29:46-63

Faber, D. J. (1966). Free-swimming copepod nauplii of Nar ragansett Bay with a key to their identification. J. Fish. Res. Bd Can. 23: 189-205

Gauld, D. T (1966). The swimming and feeding of planktonic copepods. In: Barnes, H. (ed.) Some contemporary studies in marine science. Allen and Unwin, London, p. 313-334

Guillard, R. R. (1973). Division rates. In: Stein, J. R. (ed.) Handbook of phycological methods - culture methods and growth measurements. Cambridge University Press, Cambridge, p. 289-311

Haq, S. M. (1967). Nutritional physiology of Metridia Iucens and $M$. longa from the Gulf of Maine. Limnol. Oceanogr. 12: $40-54$

Harris, R. P. (1982). Comparison of the feeding behavior of Calanus and Pseudocalanus in two experimentally ma- 
nipulated enclosed ecosystems. J. mar. biol. Ass. U. K. 62 : 71-91

Hulsizer, E. H. (1976). Zooplankton of lower Narragansett Bay, 1972-1973. Chesapeake Sci. 17: 260-270

Huntley, M. (1981). Nonselective, nonsaturated feeding by three calanoid copepod species in the Labrador Sea. Limnol. Oceanogr. 26: 831-842

Itoh, K. (1970). A consideration on feeding habits of planktonic copepods in relation to the structure of their oral parts. Bull. Plankton Soc. Japan 17: 1-10

Kiørboe, T., Mohlenberg, F., Nicolajsen, H. (1982). Ingestion rate and gut clearance in the planktonic copepod Centropages hamatus (Lilljeborg) in relation to food concentration and temperature. Ophelia 21: 181-194

Klein Breteler, W. C. M. (1980). Continuous breeding of marine pelagic copepods in the presence of heterotrophic dinoflagellates. Mar. Ecol. Prog. Ser. 2: 229-233

Landry, M. R. (1978). Predatory feeding behavior of a marine copepod, Labidocera trispinosa. Limnol. Oceanogr. 23: $1103-1113$

Landry, M. R. (1981). Switching between herbivory and carnivory by the planktonic marine copepod Calanus pacificus. Mar. Biol. 65: 77-82

Lebour, M. V. (1922). The food of plankton organisms. J. mar. biol. Ass. U. K. 12: 644-677

Lonsdale, D. J., Heinle, D. R., Siegfried, C. (1979). Carnivorous feeding by the adult calanoid copepod Acartia tonsa Dana. J. exp. mar. Biol. Ecol. 36: 235-248

Marshall, S. M. (1924). The food of Calanus finmarchicus during 1923. J. mar. biol. Ass. U. K. 13: 473-479

Marshall, S. M. (1973). Respiration and feeding in copepods. Adv. mar. Biol. 11: 57-120

Martin, J. H. (1965). Phytoplankton-zooplankton relationships in Narragansett Bay. Limnol. Oceanogr. 10: 185-191

Martin, J. H. (1970). Phytoplankton-zooplankton relationships in Narragansett Bay. IV. The seasonal importance of grazing. Limnol. Oceanogr. 15: 413-418

Mullin, M. M. (1966). Selective feeding by calanoid copepods from the Indian Ocean. In: Barnes, H. (ed.) Some contemporary studies in marine science. Allen and Unwin, London, p. 545-554

Mullin, M. M., Sloan, P. R., Eppley, P. W. (1966). Relationship between carbon content, cell volume, and area in phytoplankton. Limnol. Oceanogr. 20: 307-311

Paffenhöfer, G.-A. (1971). Grazing and ingestion rates of nauplii, copepodids and adults of the marine planktonic copepod Calanus helgolandicus. Mar. Biol. 11; 286-298
Paffenhöfer, G.-A., Knowles, S. C. (1980). Omnivorousness in marine planktonic copepods. J. Plankton Res. 2: 355-365

Poulet, S. A. (1973). Grazing of Pseudocalanus minutus on naturally occurring particulate matter. Limnol. Oceanogr. 18: $565-573$

Poulet, S. A. (1974). Seasonal grazing of Pseudocalanus minutus on particles. Mar. Biol. 25: 109-123

Poulet, S. A. (1978). Comparison between five coexisting species of marine copepods feeding on naturally occurring particulate matter. Limnol. Oceanogr. 3: 1126-1143

Richman, S., Heinle, D. R., Huff, R. (1977). Grazing by adult estuarine copepods of Chesapeake Bay. Mar. Biol. 42: $69-74$

Robertson, S. B., Frost, B. W. (1977). Feeding by an omnivorous planktonic copepod, Aetideus divergens Bradford. J. exp. Mar. Biol. Ecol. 29: 231-244

Turner, J. T. (1977). Sinking rates of fecal pellets from the marine copepod Pontella meadii. Mar. Biol. 40: 249-259

Turner, J. T. (1978). Scanning electron microscope investigations of the feeding habits and mouthpart structures of three species of copepods of the family Pontellidae. Bull. mar. Sci. 28: $487-500$

Turner, J. T. (1982). The annual cycle of zooplankton in a Long Island estuary. Estuaries 5: 261-274

Turner, J. T. (1984a). Zooplankton feeding ecology: contents of fecal pellets of the copepods Eucalanus pileatus and Paracalanus quasimodo from continental shelf waters of the Gulf of Mexico. Mar. Ecol. Prog. Ser. 15: 27-46

Turner, J. T. (1984b). The feeding ecology of some zooplankters that are important prey items of larval fish. NOAA Tech. Rep. NMFS 7: 1-28

Turner, J. T. (in press). Zooplankton feeding ecology: contents of fecal pellets of the copepods Acartia tonsa and Labidocera aestiva from continental shelf waters near the mouth of the Mississippi River. P. S. Z. N. I.: Mar. Ecol.

Turner, J. T., Anderson, D. M. (1983). Zooplankton grazing during dinoflagellate blooms in a Cape Cod embayment, with observations of predation upon tintinnids by copepods. P. S. Z. N. I: Mar. Ecol. 4: 359-374

Turner, J. T., Bruno, S. F., Larson, R. J., Staker, R. D., Sharma, G. M. (1983). Seasonality of plankton assemblages in a temperate estuary. P. S. Z. N. I: Mar. Ecol. 4: 81-99

US Department of Commerce. NOAA. National ocean survey. 1972. Tidal current tables, Atlantic coast of North America. Washington, D. C.

Wickstead, J. H. (1962). Food and feeding in pelagic copepods. Proc. Zool. Soc. Lond. 139: 545-555 